\title{
Water, water everywhere, but not a drop in sight: the impact of drug shortages on Canadian anesthesia care
}

\author{
Patricia Houston, MD • Richard Chisholm, MD
}

Published online: 27 March 2013

(C) Canadian Anesthesiologists' Society 2013

\begin{abstract}
A 38-yr-old mother of three presents for a laparoscopic appendectomy for acute appendicitis. She is a non-smoker and has a history of motion sickness. Her attending anesthesiologist advises her that she is at high risk for postoperative nausea and vomiting and that the most commonly used intravenous antiemetics are currently unavailable. The patient develops intractable vomiting in the postoperative care unit and requires three days of hospitalization as a result of a gastrointestinal hemorrhage secondary to a Mallory-Weiss type esophageal injury. Both the anesthesiologist and the patient are upset over the outcome of the anesthetic care.
\end{abstract}

Although this is a fictitious case, in April of 2012, this type of scenario was very possible in institutions across Canada. In the survey of Canadian anesthesiologists reported by Hall et al. in this issue of the Journal, 53 (20.6\%) of the 258 respondents during April 15 to June 4, 2012 noted a shortage of antiemetic agents. ${ }^{1}$ Shortages of anesthetic agents have been reported to cause life-threatening illness. During the 2010 propofol shortage in the United States, contamination of propofol single-use vials used inappropriately for multiple patients led to an outbreak of hepatitis $\mathrm{C}$ infection and the need for approximately 40,000 patients to be tested for potential infection. $^{2}$

The global pharmaceutical market is valued in excess of US\$880 billion dollars. ${ }^{\mathrm{A}}$ Canadian pharmaceutical sales

P. Houston, MD ( $₫)$

Department of Anesthesia, St. Michael's Hospital, 30 Bond Street, Toronto, ON M5B 1W8, Canada

e-mail: houstonp@smh.ca

P. Houston, MD $\cdot$ R. Chisholm, MD

Canadian Anesthesiologists' Society, Toronto, ON, Canada had an annual growth of $6.4 \%$ per year over the period 2006 to 2010, and Canada is the fourth fastest growing pharmaceutical market globally. ${ }^{\mathrm{B}}$ In spite of this growth in the pharmaceutical industry, over this same period, drug shortages have become an increasingly serious and prevalent problem in Canada and internationally.

Since 2009, the Canadian Anesthesiologists' Society (CAS) has lobbied the federal government to work in cooperation with provincial and territorial governments and industry to a) develop a nationwide strategy to anticipate, identify, and manage shortages of essential medications; b) mandate that drug manufacturers report any planned disruption or discontinuation in production to Health Canada in a timely manner; and c) expedite the review process to ensure that safe and effective medications are made available to the Canadian public. This initiative was championed by CAS Past President, Dr. Richard Chisholm. In March 2012, Dr. Chisholm gave a presentation on drug shortages to the House of Commons Standing Committee on Health on behalf of the CAS. In June 2012, this committee tabled a report, Drug Supply in Canada: a Multi-Stakeholder Responsibility. ${ }^{\mathrm{C}}$ The recommendations in this report are well aligned with those of the CAS, but as yet, the federal government has not moved

\footnotetext{
A Industry Insight: Global Pharmaceutical Industry. Available from URL: http://www.businessvibes.com/blog/industry-insight-globalpharmaceutical-industry (accessed March 2013).

B Government of Canada. Pharmaceutical Industry Profile - Canadian Life Sciences Industry. Available from URL: www.ic.gc.ca/eic/site/ lsg-pdsv.nsf/eng/h_hn01703.html (accessed March 2013).

C Smith J. Drug Supply in Canada: a Multi-Stakeholder Responsibility. Report of the Standing Committee on Health. House of Commons, Canada 2012. Available from URL: www.parl.gc.ca/content/hoc/ Committee/411/HESA/Reports/RP5640047/hesarp09/hesarp09-e.pdf (accessed March 2013).
} 
forward with a national strategy to address this important health care problem. A national Web site, available in both French and English, has been created (www.drugshortages. ca); however, at this time, the Web site is supported by funding from the pharmaceutical industry, and there is no mandatory requirement to report impending decreases in drug supply or distribution.

The CAS is working with our partner international anesthesiology societies to bring this issue to the global stage. The Association of Anaesthetists of Great Britain and Ireland has proposed the creation of a National List of Essential Medicines for Anesthesia and Intensive Care that would be more comprehensive than that currently included in the report of the World Health Organization. ${ }^{3}$ This list could be shared among the members of the World Federation of Societies of Anesthesiologists for better identification of those medications that are essential for the safe practice of anesthesiology. After the propofol shortage of 2010, the American Society of Anesthesiologists (ASA) advocated strongly for changes in the requirements for reporting and management of drug shortages. President Obama issued an executive order in October 2011 directing the Federal Drug Administration to take steps to prevent and reduce disruptions in the supply of "lifesaving" drugs. ${ }^{3}$ The ASA has also supported the creation of a National Anesthesia Clinical Outcomes Registry and an Anesthesia Incident Reporting System, both of which can be used to report and track adverse outcomes related to medication shortage.

Funding for the research completed by Drs. Hall et al. was provided by the CAS, as was access to our CAS database of anesthesia providers. Of the CAS members surveyed, 1,187 (61.4\%) responded, signifying the importance of this issue to Canadian anesthesiologists. As stated by the authors, "the current rate of drug shortages requires frequent alterations of anesthetic technique." 1 As evidenced by $7.8 \%$ of respondents who reported witnessing a drug error, changing practice is a safety hazard both at the time of a drug shortage and during re-introduction of the more commonly used medications. Almost 50\% of respondents thought they had given an inferior anesthetic, and many reported stress related to managing patients in an environment fraught with the fear of not providing optimal care.

The CAS will continue to lobby the provincial and federal governments to implement the recommendations of the House of Commons Standing Committee on Health, and further, to mandate timely reporting of decreases or discontinuation of drug supply, and to improve our systems to prevent such occurrences in the future. This is also an opportunity for the CAS to provide educational resources to our members to help them develop plans, identify therapeutic alternatives, and implement appropriate safety measures at a time affected by an unexpected drug shortage.

The article by Drs. Hall et al. highlights the need for a Canadian anesthesia registry to collect objective data regarding patient outcomes and critical incidents. To ensure that we have captured both the data and the insights of our members in future, the CAS will be seeking input from our members, either in collaboration with an international partner or with a nationally developed system, in order to progress toward a better understanding of the risks and outcomes related to drug shortages and the impact of such shortages on the delivery of anesthetic care.

\section{De l'eau, partout de l'eau, mais pas une goutte en vue: l'impact des pénuries de médicaments sur les soins en anesthésie au Canada}

Une femme de 38 ans, mère de trois enfants, se présente pour une appendicectomie par laparoscopie pour traiter une appendicite aiguë. Elle est non fumeuse et a des antécédents de mal des transports. Son anesthésiologiste lui annonce qu'elle court un risque élevé de nausées et vomissements postopératoires et que les antiémétiques intraveineux les plus couramment utilisés ne sont pas disponibles en ce moment. La patiente souffre de vomissements réfractaires en salle de réveil et est hospitalisée durant trois jours en raison d'une hémorragie gastro-intestinale secondaire à une lésion œsophagienne de type Mallory-Weiss. L'anesthésiologiste et la patiente sont tous deux mécontents du résultat des soins donnés en anesthésie.

Bien qu'il s'agisse d'un cas imaginaire, en avril 2012, ce type de scénario était tout à fait plausible dans les hôpitaux canadiens. Comme indiqué dans le sondage de Hall et coll. publié dans ce numéro du Journal, 53 (20,6 \%) des 258 anesthésiologistes canadiens interrogés entre le 15 avril et le 4 juin 2012 ont remarqué une pénurie d'antiémétiques. ${ }^{1}$ Il a été rapporté que les pénuries de médicaments utilisés pour l'anesthésie causaient des maladies potentiellement fatales. La contamination de fioles de propofol à usage unique utilisées de façon inappropriée pour plusieurs patients pendant la pénurie de propofol de 2010 aux États-Unis a provoqué une épidémie d'infections à l'hépatite C; il a fallu tester quelques 40000 patients pour dépister une infection potentielle. ${ }^{2}$

Le marché pharmaceutique mondial est évalué à plus de 880 milliards de dollars américains. ${ }^{\mathrm{A}}$ Au Canada, les ventes de produits pharmaceutiques ont affiché une croissance annuelle de 6,4 \% entre 2006 et 2010; le Canada 
est le quatrième au monde pour la croissance de son marché pharmaceutique. ${ }^{B}$ Malgré cette croissance du secteur pharmaceutique, au cours de la même période, les pénuries de médicaments sont devenues un problème de plus en plus sérieux et prévalent au Canada comme ailleurs dans le monde.

Depuis 2009, la Société canadienne des anesthésiologistes (SCA) fait pression sur le gouvernement fédéral afin qu'il coopère avec les gouvernements provinciaux et territoriaux ainsi que l'industrie pour: a) mettre en place une stratégie à l'échelle nationale pour anticiper, identifier et gérer les pénuries de médicaments essentiels; b) exiger que les fabricants de médicaments rapportent de façon opportune à Santé Canada toute perturbation ou interruption planifiée de la production; et c) accélérer le processus d'examen afin de rendre disponibles au public canadien des médicaments sécuritaires et efficaces. Le fer de lance de cette initiative était l'ancien président de la SCA, le Dr Richard Chisholm, qui a donné une conférence sur les pénuries de médicaments au nom de la SCA au Comité permanent de la santé de la Chambre des communes en mars 2012. Ce comité a présenté un rapport: L'approvisionnement en médicaments au Canada: une responsabilité multilatérale en juin 2012. ${ }^{\mathrm{C}}$ Les recommandations de ce rapport sont en ligne avec celles de la SCA. Toutefois, à ce jour, le gouvernement fédéral n'a pas proposé de stratégie nationale pour gérer cet important problème des soins de santé. Un site Internet national, disponible en français et en anglais, a été mis en ligne: www.drugshortages.ca. Toutefois, à l'heure actuelle, ce site Internet est financé par des fonds provenant du secteur pharmaceutique, et il n'y a pas d'exigence quant à la déclaration obligatoire de réductions imminentes dans l'approvisionnement ou la distribution des médicaments.

La SCA travaille de concert avec les sociétés d'anesthésiologie internationales partenaires afin d'exposer ce problème sur la scène mondiale. L'Association of Anaesthetists of Great Britain and Ireland a proposé la création de Listes nationales des médicaments essentiels pour l'anesthésie et les soins intensifs, lesquelles seraient plus exhaustives que celle actuellement incluse dans le rapport de l'Organisation mondiale de la Santé. ${ }^{3}$ Cette liste pourrait être partagée parmi les membres de la Fédération mondiale des sociétés d'anesthésiologistes afin de mieux définir

les médicaments essentiels à la pratique sécuritaire de l'anesthésiologie. Après la pénurie de propofol de 2010, l'American Society of Anesthesiologists (ASA) a préconisé fortement que des changements soient apportés aux exigences de communication et de gestion des pénuries de médicaments. En octobre 2011, le président Obama a émis un décret présidentiel exigeant de la Food and Drug Administration qu'elle prenne des mesures afin d'éviter et de réduire les perturbations dans l'approvisionnement des médicaments «d'importance vitale ». ${ }^{3}$ L'ASA a également soutenu la création d'un Registre national des pronostics cliniques en anesthésie (National Anesthesia Clinical Outcomes Registry) et d'un Système de communication des incidents en anesthésie (Anesthesia Incident Reporting System), deux outils qui peuvent être utilisés pour rapporter et suivre les pronostics défavorables liés aux pénuries de médicaments.

La SCA a financé les recherches de Dr Hall et coll., et lui a donné accès à sa base de données des fournisseurs d'anesthésie. Parmi les membres de la SCA interrogés, 1187 $(61,4 \%)$ ont répondu, un signe clair de l'importance de cette question pour les anesthésiologistes canadiens. Comme le déclarent les auteurs, "l'incidence actuelle de pénuries de médicaments requiert des modifications fréquentes des techniques anesthésiques ». ${ }^{1}$ Les changements de pratique, aussi bien lors d'une pénurie de médicaments ou lors de la réintroduction des médicaments les plus fréquemment utilisés, constituent un risque pour la sécurité, comme le montre le chiffre de 7,8\% de répondants ayant été témoins d'une erreur médicamenteuse. Près de $50 \%$ des répondants pensent avoir donné un anesthésique moins efficace et ils sont nombreux à faire état du stress ressenti en raison de la prise en charge de patients dans un environnement où régnait la peur de ne pas fournir des soins optimaux.

La SCA continuera de faire pression sur les gouvernements provinciaux et fédéral afin qu'ils mettent en œuvre les recommandations du Comité permanent de la Chambre des communes, qu'ils rendent obligatoire la communication opportune des réductions et des interruptions de l'approvisionnement en médicaments, et qu'ils améliorent nos systèmes afin d'éviter de telles situations à l'avenir. C'est là également une occasion pour la SCA d'offrir des ressources pédagogiques à nos membres, lesquelles les aideront à mettre au point des plans, à identifier des alternatives thérapeutiques et à mettre en œuvre des mesures de sécurités adaptées pour faire face aux situations où une pénurie de médicaments imprévue survient.

L'article de Dr Hall et coll. souligne la nécessité de créer un registre canadien d'anesthésie afin de récolter des données objectives concernant les devenirs des patients et les incidents cruciaux. La SCA demandera à ses membres de partager leurs idées pour progresser, soit en collaboration avec un partenaire international, soit en mettant au point un système à l'échelle nationale afin de garantir qu'à l'avenir, nous disposions des données et des idées de nos membres afin de mieux comprendre les risques et les résultats liés aux pénuries de médicaments et l'impact de telles pénuries sur la prestation des soins anesthésiques.

Competing interests None declared. 


\section{Conflits d'intérêt Aucun.}

\section{References}

1. Hall R, Bryson GL, Flowerdew $G$, et al. Drug shortages in Canadian anesthesia: a national survey Can J Anesth 2013; 60: this issue. DOI:10.1007/s12630-013-9920-z.
2. Jensen $V$, Rappaport BA. The Reality of drug shortages - the case of the injectable agent propofol. N Engl J Med 2010; 363: 806-7.

3. Ferguson $K$, Woodcock $T$. Ensuring a sustainable supply of drugs for anaesthesia and peri-operative care. Anaesthesia 2012; 67: 1313-6. 